\title{
EDITORIAL
}

\section{Hermann Lebert (1813-1878): a pioneer of diagnostic pathology}

\author{
Hellmuth Pickel • Olaf Reich • Raimund Winter • \\ Robert H. Young
}

Received: 17 July 2009 /Accepted: 31 July 2009/Published online: 18 August 2009

(C) Springer-Verlag 2009

\begin{abstract}
Hermann Lebert (1813-1879) was a pioneer of diagnostic pathology and medical iconography. He was born in Breslau, then Prussia, and died in Nice (France). He lived in Switzerland as a general physician, in France as a pathologist, and eventually became the chairman for internal medicine in Zurich and Breslau, respectively. The significance of Hermann Lebert for medical posterity has three aspects: firstly, scientific linking of the French (Parisian) school and its distinctive clinical/practical orientation to the later clinical/pathological German school of Johann Lukas Schönlein, Johannes Müller, and Rudolf Virchow; secondly, his pioneering of the diagnostic use of the microscope in pathological anatomy; and finally, his remarkable book, Traité d'anatomie pathologique générale et spéciale, which has almost fallen into oblivion, being unknown to most contemporary workers.
\end{abstract}

Keywords Pathologist · Microscopy · Cytology ·

Pathologic atlas

Most who read these words use a microscope as part of their routine work as a diagnostic pathologist without giving any thought, quite reasonably, to when this modality first became used in medical care. If they do, they may

\footnotetext{
H. Pickel $(\bowtie) \cdot$ O. Reich $\cdot$ R. Winter

Department of Gynecology, Medical University of Graz, Auenbruggerplatz 14,

A-8036 Graz, Austria

e-mail: ulli.pickel@aon.at

R. H. Young

James Homer Wright Pathology Laboratories,

Department of Pathology, Massachusetts General Hospital,

Harvard Medical School,

Boston, USA
}

think it has been since not long after the time of Van Leeuwenhoek. However, at least one authority on the history of pathology has noted the rather surprising delay in the utilization of the microscope in the practice of pathology [1], and indeed, if one views our discipline from the broad perspective of human history, light microscopic analysis of tumors and other lesions is still relatively "new." In this essay, we consider one of the pioneers of microscopy in pathology, Hermann Lebert, and discuss his books, one of which is surely one of the most magnificent in the rich tradition of diagnostic pathology.

It is a sad reality that, with the passage of time, remarkable contributions of prior investigators and even the investigators themselves often become progressively overlooked and, in some cases, end up completely unknown by current workers. This includes some whose innovation can be considered fundamental to the development of our field. We recently came across the stunning book Traité d'anatomie pathologique générale et spéciale [2] by the French/German physician-pathologist Hermann Lebert. It stimulated us to investigate his life and other contributions [3, 4], which, although noted in standard books on the history of pathology $[1,5,6]$, we suspect, are either not known or are little known by most readers. Our researches clearly indicated a person of great substance whose contributions merited exposition for the current generation.

Paris was the center of the medical world in the early years of the nineteenth century when a transition from speculative medicine to medicine based on rational observation was taking place. The new "philosophy of observation" had its breakthrough due to the Enlightenment and the French Revolution of 1789. In 1794, the teaching of medicine and the organization of the hospitals in France underwent a radical reform. It was mostly clinicians, and primarily surgeons, who benefited from this. Thanks to the 
vast number of patients in the large Parisian hospitals; they had ample opportunity to practice bedside observation. Aside from focusing on observation and care of patients, they also emphasized pathological anatomy, largely autopsy based. In France and Great Britain, clinicians were regularly in charge of postmortem examination at the large hospitals up to the twentieth century. The first half of the nineteenth century saw the creation of textbooks and manuals of pathological anatomy, mainly in France, which remained standard works for a long time. They were profusely illustrated masterpieces of macroscopic iconography, with little to no consideration of the microscopic dimension, which was yet to be fully developed [7].

Hermann Lebert was born in Breslau (then in the kingdom of Prussia, now Wroclaw in Silesia/Poland) on June 9, 1813, the son of a Prussian merchant Isidore Jakob Lebert and his wife Johanna, nee Fanty [8]. His parents lived primarily in Berlin (then the capital of the Kingdom of Prussia) but fled to Breslau for a brief period of time to escape the conditions caused by one of the Napoleonic wars (1813-1814).

Lebert studied medicine and the natural sciences in Berlin and then in Zurich under Johann Lukas Schönlein (1793-1864). Before and after receiving his medical doctorate at the University of Zurich in 1834, Lebert traveled with his close friend Jean de Charpentier (17861855) throughout Switzerland and studied botany. After receiving a doctorate with a thesis on botany, he focused on theoretical and practical medicine for the next $11 / 2$ years. In Paris, he attended postgraduate courses, particularly under two famous figures in the history of medicine, the surgeon Guillaume Dupuytren (1777-1835) and the physician-pathologist Pierre Charles Alexandre Louis (17871872), the father of medical statistics. In 1838, Lebert began to work as a country doctor in Bex, a mountainous village in the Rhone Valley in the Swiss Canton of Vaud. During the summer months, he practiced medicine in Bex, but he spent the winter months of 1842-1845 in Paris, occupied with both clinical and microscopic studies in the great Paris hospitals. He attended the microscopic courses of the prominent French clinician and microscopist Alfred Francois Donné (1801-1878) (chef de clinique at the Hopital de la Charite in Paris, the discoverer of thrombocytes, trichomonades, and Candida albicans and the inventor of microphotography) [9]. In Paris, he became friends with his later pupils, the pathologist/clinician Charles Robin (1821-1885) and Paul Broca (1824-1880). In 1844, he witnessed the short but bloody civil war in the Swiss canton of Valais, where he served as an army doctor. During a stay in Berlin in the winter of 1845-1846, he made the acquaintance of two promising German pathologists (later to become legendary figures), Johannes Müller (1801-1858) and Rudolf Virchow (1821-1902), who both became his friends.
Fig. 1 a Portrait of Professor Hermann Lebert. b Frontispiece of the main work of Lebert. c Diseases of the liver (above abscess of the liver, below cirrhosis hepatis). On the right side of the picture under figure 4, cytologic native preparations of degenerated liver cells. d Native cytologic preparations of diverse tumors, epidermoid cancer cells with psammoma bodies (figures 1 and 2), isolated cells with multiple nuclei (figure 4). e Kidneys with hydronephrotic alterations (figure 1, upper left and right) and polycystic alterations in the middle bottom (figure 4). Between the figures, native preparations of sedimentary crystals. f Gynecological cancers: cancer of the cervix (upper left and right, figures 1 and 4), Cervical cancers with perforation into the bladder (figures 2 and 6 ). On the bottom right (figure 7, endometritis after artificial abortus with perforation. In the middle on the right side (figure 3), native cytologic preparations of squamous cancer cells. In figure 5 (middle bottom) native cancer tissue with blood vessels

In 1846, Lebert finally moved to Paris, devoting his efforts to his extensive private practice in the morning and to his scientific work in the afternoon and evening. These years saw the beginning of his work on his monumental iconography of pathological anatomy (see later). The previous year, 1845, saw the publication of his first book, considered by us later. In 1848, he experienced the February revolution in Paris, and in 1849, he witnessed the outbreak of cholera, in the same city, which resulted in 10,000 deaths. For his work combating that epidemic, he received the cross of the Legion d'honneur from the French president Louis Napoleon Bonaparte (later Emperor Napoleon III, 1808-1873). He left Paris and went to Zurich in 1852; there, he was appointed professor of clinical medicine at the university. He resigned from this position in 1859 when he was offered a similar position at the University of Breslau. In the same year, 1853, he married Isaline Fayod with whom he had five children. He witnessed the Austro-Prussian war in Breslau in 1866 and served again as a high-ranking military officer in the Prussian army. In 1869 , he took part in the fight in Silesia against another epidemic, typhoid fever, as the medical adviser for the city of Breslau. He resigned from his position in Breslau in 1874 and divided his time in the last 4 years of his life between Nice, France and Vevey and Bex in Switzerland. He died in Bex on August 1, 1878, from rupture of an aortic aneurysm. He is buried in Nice [8].

Hermann Lebert was a very prolific author and added greatly to the knowledge of biology, pathology, and clinical medicine of his time [10, 11]. In his autobiography, published in 1869, he listed 101 major contributions [12]. However, Reichert, in a subsequent biography, listed 124 publications [8]. The most prominent among them is the colossal Traité d'anatomie pathologique générale et spéciale published in four volumes (two volumes text and two volumes atlas) edited by Baillière in Paris in 1857 and 1861 [2]. Lebert subtitled his work Description et iconographie pathologique. This is one of the most comprehensive and important work of the pre-photographic era of medical 

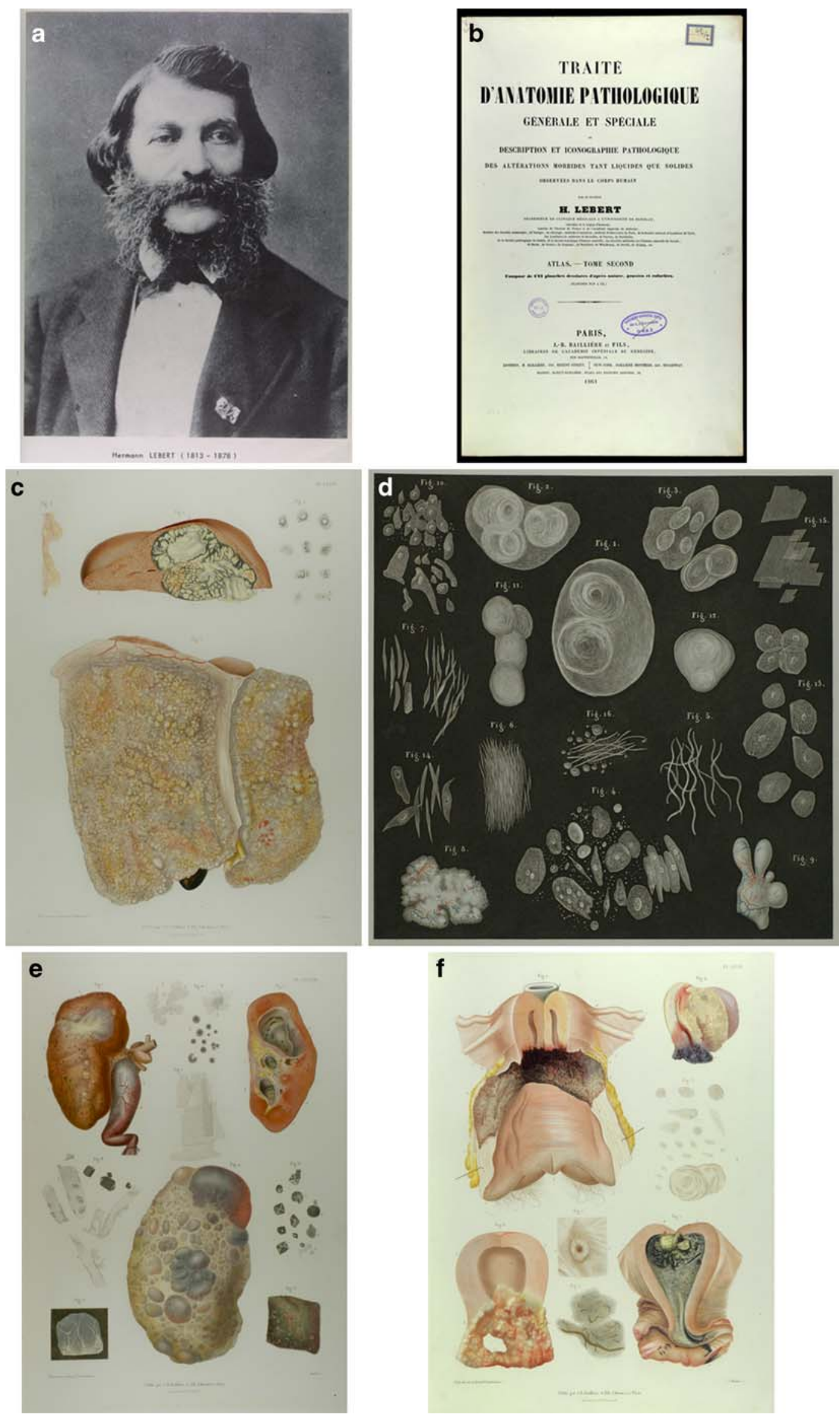
illustration (Fig. 1). Contributors to the enormous pathological and clinical material contained within it were physicians from Paris, most notably the surgeons AlfredArmand Velpeau (1795-1867) and Charles Marie Edouard Chassaignac (1805-1879) as well as the syphilidologist Philippe Ricord (1799-1889).

The quality of Lebert's work has only been equaled in our times by means of color photography. Apparently, the illustrations were steel-faced copper engravings using multiple plates printing ("Planches dessinées d'aprés nature, gravées et coloriées"), and their technical quality is superb [7]. This was aided by having it printed by the most renowned publishing house of that time, J.-B. Baillière et fils in Paris, which had also published and printed Cruveilhier's magnum opus. The composition of Lebert's atlas resembles the work of his great predecessor Cruveilhier, but it is much larger and has a richer layout. In contrast to Cruveilhier's work, Lebert combines his text in two complete and well-arranged volumes and provides detailed and clear explanations in the two atlases [1] Lebert surpasses the work of Cruveilhier by not only describing microscopic findings but also by documenting them in detail in his illustrations as well.

The work consists of four volumes in large folio size (12 $1 / 4$ in. wide $\times 183 / 4$ in. tall): two text volumes (766 and 733 pages) as well as two atlas volumes (the first volume featuring 94 tables ("planches") including several illustrations and 46 pages of explanations, and the second volume 106 tables with several pictures and 44 pages of explanations). This work was sold to more than 300 subscribers throughout the world. Most of the subscribers were large university libraries both in Europe and the Americas, primarily the USA. However, bookstores and individuals also appear as subscribers. In 1863, Lebert's work received an award from the Imperial French Medical Academy. These words do not do justice to Lebert's work, which proverbially "needs to be seen to be believed."

The first volume contains a historical overview of pathological-anatomical iconography followed by a comprehensive essay on general pathology with relevant clinical case histories. The second volume is entirely dedicated to special pathology and also includes case histories and, among them, cases of tumor pathology. The scope of the two atlases is remarkable with the 200 large and mainly colored plates of the highest quality designed by outstanding artists such as the draftsman Lackerbauer and the engravers Oudet and Visto. The complete work was produced by the fine-art printers L. Martinet in Paris. To further emphasize the magnificence of the work, we note that each plate contains a minimum of ten and usually many more individual illustrations.

Lebert's most historically significant other publication was his two-volume Physiologie pathologique published in 1845 [3]. In it, he combines clinical observation, animal experiments, and microscopic observations as well as biochemistry. The first volume deals with inflammatory disorders. The second volume deals exclusively with tumors. Lebert expresses his theory of the characteristics of malignant cells for the first time in this work; this would become very controversial later. By means of uncolored cytological preparations, he described the morphological features of neoplastic cells, which are still valid today, such as those pertaining to the nucleolus.

The importance of the aforementioned work was brought home to us while we were preparing this essay, devised initially mainly to draw attention to the remarkable two volume text and atlas already considered. As part of the associated reading of various texts, we consulted the small but wonderfully detailed and strongly recommended book on the history of pathology by Dr. E. B. Krumbhaar published in 1937 [1]. In his chapter on "cellular pathology," which considers primarily Virchow, Krumbhaar reflects on the relatively late application of the microscope in the study of morbid anatomy we noted earlier. The first work Krumbhaar credits for applying microscopy to pathologic anatomy is the 1843 book of Julius Vogel Icones Histologicae Pathologicae. He then notes the 1845 work of Lebert, making it, obviously, one of the earliest works in which microscopy was used in the pathology literature. Similar significance is given to Lebert's 1845 book in Long's consideration of the History of Pathology [5], and these observations are reinforced by Dr. Steven Hajdu [13], in a much more recent contribution, and in the outstanding recent book on the History of Histopathology by Professor Georg Dhom [9].

Lebert figures in a significant way in the second chapter of the latter work when Dhom discusses the Paris school. Indeed, Lebert gets more coverage in that chapter than any other individual, and Dhom illustrates the frontispiece of two of his books as well as a number of other illustrations from his texts. The mention Lebert has received in these contributions only heightened our feeling that his role in the development of diagnostic pathology merited further highlighting. However, despite the attention he received in the works just noted, we feel that, overall, he is not as wellknown as he should be to most current workers. Lebert wrote a third book published in 1851 [4]. Like all his works, the work is an impressive one, albeit not as monumental as the Atlas we have focused on. The 1851 book runs to 885 pages and is divided into two parts. The first has four chapters concerning the microscopic characteristics of neoplasia and the second part ten chapters considering separate organs and systems of the body in turn. Among those he dedicates the work, three are giants, such as Cruveilhier, Louis, and Müller.

Very early in his career, Lebert advocated the diagnostic use of the microscope in the assessment of biopsy material [14] following the pioneering work of Alfred Donné. There 
was no practical technique for dying tissue at the time, and observers had to rely on the assessment of individual cells or, at best cell clusters, from cytological preparations [9]. Thus, Lebert propagated the "Stückchen-diagnose" (small piece diagnosis of malignant tumors) decades before Ruge [15] and Veit [16] did. In his role as director of the Medical Clinic in Breslau/Wroclaw, Lebert emphasized: "Uterine cancer must be diagnosed directly in life by means of a microscope in that one can examine larger pieces of tissue" [17].

Lebert's other important publications (for a complete list, see references) focused on botany and zoology (entomology) as well as medical/historical topics. Publications from his early years were in French, but the majority of those dating from the beginning of his academic career and his call to Zurich in 1853 was written in German.

The significance of Hermann Lebert for medical posterity has three aspects: firstly, scientific linking of the French (Parisian) school and its distinctive clinical/practical orientation to the later clinical/pathological German school of Johann Lukas Schönlein, Johannes Müller and Rudolf Virchow; secondly, his pioneering of the diagnostic use of the microscope in pathological anatomy; and finally, his remarkable book, Traité d'anatomie pathologique générale et spéciale, which has almost fallen into oblivion, being unknown to most contemporary workers.

Acknowledgements Mr. Jack Eckert, Senior Librarian at the Center for the History of Medicine at the Francis A. Countway Library of Medicine at Harvard Medical School, was most helpful in enabling review by one of the authors (RHY) of the three books of Lebert noted herein. His assistance is much appreciated. Dr. Gregory Y. Lauwers, Director of Surgical Pathology at the Massachusetts General Hospital kindly translated selected portions of Lebert's atlas for RHY.

\section{References}

1. Krumbhaar EB (1937) Pathology. In: Hoeber PB (ed) Clio Medica: a series of primers on the history of medicine, vol 19. Hoeber, New York, pp 96-106
2. Lebert H (1857) Traité d'anatomie pathologique générale et speciale. Description et iconographie pathologique des altérations morbides tant liquides que solides. J.-B. Baillière et fils, Paris (2 volumes en grand in-folio et 2 volumes du même format de 200 planches gravées en acier et coloriées)

3. Lebert H (1845) Physiologie pathologieque ou reserches cliniqiues, experimentales et microscopiques. Sur l'inflammation, la tuberculisation, les tumeur la formation du cal. Chez J-B Baillière, Paris

4. Lebert H (1851) Traité pratique des maladies cancéreuses et des affections curables confondues avec le cancer. Chez J-B Baillière, Paris

5. Long ER (1965) A history of pathology. Dover, New York

6. Malkin H (1993) Out of the mist. The foundations of modern pathology and medicine during the nineteenth century. Vesalius, Berkeley

7. Goldschmid E (1925) Entwicklung und Bibliographie der pathologisch anatomischen Abbildung (Development and bibliography of the pathological-anatomical illustration). Hiersemann, Leipzig

8. Reichert B (1973) La vie et les oevres de Hermann Lebert. Thèse pour le doctorat en médecine, Académie de Paris, Université René Descartes, Faculté de médecine Necker-Enfants-Malades, Paris

9. Dhom G (2001) Geschichte der Histopathologie (History of histopathology). Springer, Berlin

10. Kaufmann G (1911) Festschrift zur Feier des hundertjährigen Bestehens der Universität Breslau (Publication celebrating the 100th anniversary of the university of Breslau). Hirt, Breslau

11. Nachruf auf H. Lebert (Obituary on H. Lebert) (1878) Berliner Klin Wochenschr 15:589

12. Lebert H (1869) Biographische Skizzen und Überblick der von mir bekannt gemachten Werke und kleineren Arbeiten (Biographical sketches and overview of my works and smaller treatises). Korn, Breslau

13. Hajdu SI (2004) A note from history: the first cellular pathologists. Annals of Clinical \& Laboratory Science 34:481-483

14. Lebert H (1848) Einige Bemerkungen über die Erkenntnis des Krebses vor der Operation und am Lebenden überhaupt (Some remarks on the knowledge of the cancer before the operation and on the living also). Roses und Wunderlichs Archiv für physiologische Heilkunde 7:441-445

15. Dallenbach-Hellweg G, Schmidt D (2003) History of gynecological pathology. XV. Dr. Carl Arnold Ruge. Int J Gynecol Pathol 23:83-90

16. Pickel H, Winter R, Young RH (2009) History of gynecological pathology. XXII. Johann Veit. Int J Gynecol Pathol 28:103-106

17. Lebert $H$ (1860) Handbuch der praktischen Medizin (Handbook of the practical medicine), 2nd edition, 2nd volume. Laupp'sche Buchhandlung, Tübingen 